\title{
Níveis de proteína em dietas de suínos em fase de crescimento e terminação
}

\author{
Messias Alves da TRINDADE \\ NETO ${ }^{1}$ \\ Dirlei Antônio BERTO² \\ Ricardo ALBUQUERQUE ${ }^{1}$ \\ Eliana Aparecida \\ $\mathrm{SCHAMMASS}^{3}$ \\ Willian Correa MIGUEL
}

Correspondência para:

Messias Alves da Trindade Neto, Departamento de Nutrição e Produção Animal da FMVZ - USP, Avenida Duque de Caxias Norte, 225, 13630-000 Pirassununga-SãoPaulo, messiasn@usp.br

Recebido para publicação: 21/09/2007 Aprovado para publicação: 29/06/2009

\author{
1 - Departamento de Nutrição e Produção Animal da Faculdade de Medicina \\ Veterinária e Zootecnia da Universidade de São Paulo, Pirassununga-SP \\ 2 - Departamento de Produção Animal da Faculdade de Medicina Veterinária e \\ Zootecnia da Universidade Estadual Paulista, Botucatu-SP \\ 3 - Instituto de Zootecnia, Nova Odessa-SP
}

\section{Resumo}

Fêmeas e machos castrados, em fase de crescimento e terminação, foram submetidos a diferentes níveis de proteína em dietas com e sem suplementação de aminoácidos industriais. Foram utilizados 72 animais, 36 de cada sexo, com pesos médios iniciais de 30,73 e 30,38 $\mathrm{kg}$ (fase de crescimento) e 61,08 e 57,31 kg (fase de terminação), respectivamente. Adotou-se o delineamento blocos ao acaso com três tratamentos, seis repetições e dois animais por unidade experimental. Os tratamentos corresponderam a dietas com os níveis de protéicos: 19,40; 16,80 e 14,90\% na fase crescimento e 17,8; 15,40 e $13,60 \%$ na fase terminação. $\mathrm{Na}$ fase de crescimento, as dietas com 16,80 e 14,90\% de proteína bruta são as indicadas para fêmeas e machos castrados, respectivamente. $\mathrm{Na}$ fase de terminação, a dieta com 17,80\% de proteína bruta, sem aminoácidos suplementares, seria indicada para fêmeas e machos castrados da genética estudada se o custo do farelo de soja for viável para assegurar a concentração de lisina digestível estuda e o retorno econômico. Preços do farelo de soja, dos aminoácidos industriais e do suíno determinarão a viabilidade da estratégia alimentar nessas fases do desenvolvimento. Outro fator na adoção dos níveis protéicos aplicados aos machos castrados na fase de terminação é o preço do suíno pago pelo frigorífico, no caso da classificação de carcaça, uma vez que a redução dietética da proteína implica em maior acúmulo de gordura corporal.

\section{Introdução}

A suinocultura mundial vem experimentando intenso melhoramento genético, selecionando e produzindo suínos de elevado potencial de crescimento, eficiência alimentar e composição de carcaça. Tais melhorias se associam à modificação de características fisiológicas, dependentes do aporte de nutrientes nos processos de síntese, envolvidos no crescimento. Para atender o aporte de aminoácidos nas demandas de manutenção e do crescimento, as dietas de suínos, normalmente, são formuladas baseando-se na proteína bruta.

A redução protéica da dieta, com a suplementação dos principais aminoácidos pode ser, economicamente, viável, sobretudo, quando houver constante valorização de ingredientes protéicos. Situação freqüente no Brasil, em relação ao farelo de soja, cujo preço é determinado pelo mercado internacional. ${ }^{1}$

Os passos metabólicos que envolvem a eliminação do nitrogênio, proveniente do excesso de aminoácidos, representam gasto de energia, também com reflexos negativos no custo de produção. ${ }^{2,3}$ Com a redução da concentração protéica da dieta, fazendo-se a suplementação dos principais aminoácidos, de modo a garantir o balanço entre os mesmos, surgiu o conceito da proteína ideal. Esse conceito estabelece que as relações entre os aminoácidos considerados essenciais 
sejam mantidas ${ }^{4,5,6}$ permitindo-se dentro de limites fisiológicos, a redução dietética da proteína com desempenho satisfatório e redução da excreção de nitrogênio na produção de suínos.

Objetivou-se com a presente avaliação, aferir os efeitos da variação protéica da dieta no desempenho e características de carcaça de suínos machos castrados e fêmeas, durante as fases de crescimento e terminação.

\section{Material e Método}

O estudo foi conduzido na Unidade Experimental do Pólo Regional Centro-Sul da Secretaria de Agricultura e Abastecimento do Estado de São Paulo, Piracicaba.

Em dois ensaios simultâneos, com animais nas fases de crescimento e terminação, foram utilizados 36 suínos machos castrados e 36 fêmeas com os respectivos pesos médios iniciais: 30,73 \pm 0,79 e 30,38 $0,823 \mathrm{~kg}$ na fase de crescimento; e $61,08 \pm 1,22$ e $57,31 \pm 1,07 \mathrm{~kg}$ na fase de terminação.

Os animais foram distribuídos em delineamento de blocos ao acaso, com três tratamentos, seis repetições e dois animais por unidade experimental. A formação dos blocos foi orientada pelo peso inicial dos animais e o controle experimental ocorreu ao início e final de cada fase do período experimental. As fases consideradas foram dos 30 aos $60 \mathrm{~kg}$ e dos 60 aos $95 \mathrm{~kg}$.

Os tratamentos foram os níveis dietéticos 19,40 e $17,80 \% ; 16,80$ e $15,40 \%$; 14,90 e $13,30 \%$ de proteína bruta (PB) nas fases de crescimento e terminação, respectivamente. $\mathrm{Na}$ elaboração das dietas experimentais, apresentadas na tabela 1 , adotaram-se níveis nutricionais que atendessem as exigências e relações mínimas entre lisina, treonina, metionina e triptofano em cada fase da criação. ${ }^{7}$ Nas dietas não suplementadas de aminoácidos industriais flexibilizou-se a concentração protéica para que fosse assegurada a concentração estipulada para lisina digestível. À medida que se reduziu o nível de proteína, suplementaram-se os principais aminoácidos buscando sempre o custo mínimo para cada dieta. A alimentação e água foram oferecidas à vontade.

Os animais foram alojados em baias de $2 \times 1 \mathrm{~m}$, construídas em estrutura metálica sobre piso de cimento, contendo bebedouros do tipo chupeta e comedouros para abastecimento diário, no interior de um galpão de alvenaria com forro de laje, com pé-direito de 3,20 metros, dispondo nas laterais janelas do tipo basculante para controle da ventilação. $\mathrm{O}$ acesso às instalações era restrito aos funcionários da unidade.

As pesagens dos animais para avaliação do desempenho foram realizadas no início e ao final de cada período experimental. Os ganhos relativos foram determinados a partir das fórmulas: Ganho em peso relativo $=[($ Peso final - Peso inicial)/Peso inicial] x 100; e o Ganho em peso relativo ajustado/período em dias $=\left[\left(\right.\right.$ Ganho em peso $/$ dia $\times \mathrm{n}^{\circ}$ de dias no período)/Peso inicial] x 100 .

A margem bruta (MB) devido à alimentação foi determinada pela fórmula: $\mathrm{MB}=$ (peso ao final do período de avaliação x R \$/kg do suíno) - (Consumo de ração total $\times \mathrm{R} \$ / \mathrm{kg}$ ração) - (peso inicial x $\mathrm{R} \$ / \mathrm{kg}$ do suíno). ${ }^{8}$ Nos cálculos levaram-se em conta os períodos médios transcorridos nas fases de crescimento e terminação. No intuito de uniformizar a comparação, o período médio foi corrigido para o menor número de dias, gastos por tratamento. $\mathrm{Na}$ avaliação com fêmeas foram considerados 36 dias na fase crescimento e 35 dias na fase terminação, enquanto para machos castrados foram 33 dias no crescimento e 39 dias de terminação. Nesta avaliação, o preço do quilo suíno, no início da avaliação, saída de creche, foi estabelecido em $10 \%$ do preço vigente da arroba suína. Determinou-se o índice de eficiência econômica. ${ }^{9}$

Ao final da fase de terminação os animais foram abatidos para medições nas carcaças segundo o método brasileiro de classificação de carcaça. ${ }^{10}$ Uma medida adicional de espessura de toucinho foi mensurada a $6,5 \mathrm{~cm}$ da linha dorsal $\left(\mathrm{P}_{2}\right){ }^{11}$ 
Tabela 1 - Composição centesimal das dietas experimentais nas fases de crescimento e terminação

\begin{tabular}{|c|c|c|c|c|c|c|}
\hline \multirow{2}{*}{$\begin{array}{l}\text { Ingredientes } \\
\text { Niveis de PB (\%) }\end{array}$} & \multicolumn{3}{|c|}{ Crescimento } & \multicolumn{3}{|c|}{ Teminação } \\
\hline & 19,40 & 16,80 & 14,90 & 17,80 & 15,40 & 13,30 \\
\hline Milho moido: & 67,69 & 73,09 & 77,61 & 72,25 & 77,82 & 81,88 \\
\hline Farelo de trigo & 0,00 & 1,50 & 4,50 & 0,00 & 1,00 & 3,50 \\
\hline Farelo de soja : & 29,34 & 22,0 & 14,0 & 25,00 & 18,00 & 11,00 \\
\hline Fosfato bicálecico : & 1,23 & 1,30 & 1,30 & 1,00 & 1,10 & 1,10 \\
\hline Calcário : & 0,92 & 0,95 & 1,00 & 0,95 & 0,95 & 1,00 \\
\hline Sal & 0,50 & 0,50 & 0,50 & 0,50 & 0,50 & 0,50 \\
\hline $\mathrm{L}-\mathrm{L}$ is ina $\mathrm{HCl}$ & 0,00 & 0,24 & 0,45 & 0,00 & 0,22 & 0,42 \\
\hline L-treonina & 0,00 & 0,05 & 0,15 & 0,00 & 0,05 & 0,14 \\
\hline DL-Metionina & 0,00 & 0,02 & 0,09 & 0,00 & 0,00 & 0,05 \\
\hline L-triptofano & 0,00 & 0,00 & 0,03 & 0,00 & 0,00 & 0,03 \\
\hline Cloreto de colina & 0,02 & 0,05 & 0,07 & 0,00 & 0,06 & 0,08 \\
\hline Suplemento vitamínico/mineral ${ }^{2}$ & 0,30 & 0,30 & 0,30 & 0,30 & 0,30 & 0,30 \\
\hline Total & 100 & 100 & 100 & 100 & 100 & 100 \\
\hline \multicolumn{7}{|l|}{ Valores calculados } \\
\hline EM, kcalkg & 3210 & 3220 & 3220 & 3230 & 3240 & 3240 \\
\hline Gordura (\%) & 2,93 & 3,14 & 3,32 & 3,06 & 3,25 & 3,42 \\
\hline Fibra bruta $(\%)$ & 3,35 & 3,08 & 2,94 & 3,13 & 2,86 & 2,73 \\
\hline Cinzas (\%) & 5,46 & 5,16 & 4,92 & 5,07 & 4,78 & 4,56 \\
\hline Cálcio (\%) & 0,75 & 0,74 & 0,74 & 0,69 & 0,68 & 0,68 \\
\hline Fósforo total $(\%)$ & 0,57 & 0,56 & 0,56 & 0,52 & 0,51 & 0,51 \\
\hline Fós foro disponivel (\%) & 0,34 & 0,34 & 0,34 & 0,30 & 0,30 & 0,30 \\
\hline Lisinat total (\%) & 1,03 & 1,01 & 0,99 & 0,92 & 0,90 & 0,88 \\
\hline Lis ina digestivel (\%) & 0,90 & 0,90 & 0,90 & 0,80 & 0,80 & 0,80 \\
\hline Treonina total $(\%)$ & 0,75 & 0,68 & 0,67 & 0,69 & 0,62 & 0,61 \\
\hline Treonina digestivel $(\%)$ & 0,64 & 0,58 & 0,58 & 0,59 & 0,54 & 0,54 \\
\hline Metionina total $(\%)$ & 0,33 & 0,32 & 0,35 & 0,31 & 0,28 & 0,30 \\
\hline Metionina digestivel (\%) & 0,30 & 0,30 & 0,33 & 0,29 & 0,26 & 0,28 \\
\hline Metionina+cistina total (\%) & 0,66 & 0,61 & 0,60 & 0,62 & 0,55 & 0,54 \\
\hline Metioninatcistina digestivel (\%) & 0,58 & 0,54 & 0,54 & 0,55 & 0,49 & 0,48 \\
\hline Triptofano total (\%) & 0,23 & 0,19 & 0,18 & 0,21 & 0,17 & 0,16 \\
\hline Triptofano digestivel $(\%)$ & 0,20 & 0,16 & 0,16 & 0,18 & 0,14 & 0,14 \\
\hline Isoleucina total $(\%)$ & 0,95 & 0,77 & 0,61 & 0,85 & 0,69 & 0,55 \\
\hline Isoleucina digestivel (\%) & 0,86 & 0,70 & 0,55 & 0,77 & 0,62 & 0,49 \\
\hline Valina total (\%) & 0,93 & 0,79 & 0,66 & 0,86 & 0,73 & 0,61 \\
\hline Valina digestivel (\%) & 0,83 & 0,70 & 0,58 & 0,76 & 0,64 & 0,53 \\
\hline Colina $(\%)$ & 1,20 & 1,20 & 1,20 & 1,00 & 1,20 & 1,20 \\
\hline
\end{tabular}

${ }^{1}$ Análises realizadas no Laboratório de Bromatologia do CNAA - IZ; ${ }^{2}$ Quantidade/3 kg de suplemento: vit. A 1.000 .000 UI, vit. D3 250.000 UI, vit. E $1.812,5 \mathrm{mg}$, Ác. Fólico $75 \mathrm{mg}$, Ácido pantotênico $2000 \mathrm{mg}$, Biotina $6,25 \mathrm{mg}$, Niacina $3.000 \mathrm{mg}$, Piridoxina $250 \mathrm{mg}$, Riboflavina 700mg, Tiamina 250mg, vit. B12 3750mcg, K3 125mg, Colina 78,3g, Antibiótico 84.000mg, Antioxidante $30.000 \mathrm{mg}$, Cu $30.000 \mathrm{mg}$; Zn 160.000mg; I 1900mg; Fe $100.000 \mathrm{mg}$; Mn $70.000 \mathrm{mg}$, Se $75 \mathrm{mg}$ 
Conforme o supracitado, o menor período médio de permanência das fêmeas até a terminação decorreu da programação de abate, quando essas foram destinadas ao abatedouro alguns dias antes dos machos.

As características determinadas no desempenho e nas carcaças foram submetidas à análise de regressão por polinômios ortogonais ${ }^{12}$ conforme modelo: $\mathrm{Y}_{\mathrm{ij}}=\mu+\mathrm{A}_{\mathrm{i}}+\mathrm{B}_{\mathrm{i}}+\mathrm{e}_{\mathrm{ij}}$, sendo: $\mathrm{Y}_{\mathrm{ij}}$ : constante associada a todas observações; $\mu$ : média geral da variável; $A_{i}$ : efeito do nível de proteína i, sendo $i=1,2$ e $3 ; B_{j}$ : efeito do bloco $j$, sendo $j=1$, 2, 3, 4, 5 e 6 ; eij = erro aleatório associado a cada observação.

\section{Resultados e Discussão}

Ao longo do experimento as médias climáticas da região foram: temperatura máxima $30,8{ }^{\circ} \mathrm{C}$; temperatura mínima $18,9^{\circ} \mathrm{C}$; umidade relativa máxima $95,91 \%$; umidade relativa mínima 50,19\%. No interior do galpão a temperatura média foi de $26,6{ }^{\circ} \mathrm{C}$, caracterizando a prevalência de situações de ambiente acima da faixa considerada como sendo a de conforto térmico para animais nas respectivas fases de desenvolvimento.

Os resultados do desempenho das fêmeas nas fases de crescimento e terminação, bem como as características de carcaça ao abate e avaliação econômica dos tratamentos, são apresentados na tabela 2 .

Não foram constatadas diferenças estatísticas nas variáveis de desempenho ao final da fase crescimento. As diferenças numéricas apresentadas, não obstante, sugerem algumas observações: o ganho relativo expresso em porcentagem; o ganho em peso; a conversão alimentar; e o número de dias demandados na fase; indicam o nível dietético de proteína $16,80 \%$ como sendo o mais favorável. Tais sugestões são ratificadas na avaliação econômica, quando foram considerados os custos finais de cada tratamento, obtidos pela da margem bruta devido à alimentação e o índice de eficiência econômica. Em algumas situações, as diferenças não detectadas na avaliação estatística podem ter implicações relevantes quando se considera o aspecto econômico ao término de cada fase experimental. ${ }^{13}$

No presente estudo, considerada a avaliação estatística do desempenho ponderal, o ajuste e suplementação dos principais aminoácidos, próximas às relações estabelecidas ${ }^{7}$ permitiram a redução do nível de proteína da dieta sem efeitos expressivos no desempenho das fêmeas. Ausência de respostas significativas nas variáveis do desempenho já foi constatada previamente, quando estudaram diferentes níveis protéicos para suínos na fase de crescimento. ${ }^{14,15}$

A redução da proteína, todavia, implicou na necessidade suplementar dos principais aminoácidos e mostrou-se viável economicamente. Excetuando as dietas sem suplementação de aminoácidos industriais que continham maior concentração protéica para assegurar o teor de lisina previsto, as demais formulações apresentadas são consideradas como de padrão comercial. Nesse caso, para garantir a concentração de lisina digestível, a suplementação de L-lisina, L-treonina e DL-metionina viabilizou a redução do farelo de soja em $25 \%$ na dieta com $16,80 \%$ de proteína bruta, comparada à dieta com maior concentração protéica $(19,40 \%)$. Observações semelhantes foram apresentadas por Figueroa et al. ${ }^{4}$ ao variarem níveis da proteína bruta em dietas destinadas a suínos na fase de crescimento. Apesar de não usarem níveis tão elevados de proteína bruta, os autores tiveram a mesma preocupação com a suplementação dos aminoácidos limitantes e reduziram de 16 para $12 \%$ a proteína dietética, procurando manter a relação ideal entre os aminoácidos das rações.

Resultados distintos foram observados por Orlando et al. ${ }^{16}$ quando concluíram que fêmeas dos 30 aos $60 \mathrm{~kg}$ exigiriam 18,26\% de proteína bruta na ração. Nesse estudo, entretanto, o consumo diário da proteína e ingestão de lisina total foi associado ao desempenho e composição de carcaça, quando os animais estiveram sob ambiente de alta temperatura.

$\mathrm{Na}$ fase de terminação, diferentemente 
Tabela 2 - Desempenho de fêmeas e características de carcaça nas fases de crescimento e terminação alimentadas com dietas com diferentes níveis de proteína

\begin{tabular}{|c|c|c|c|c|}
\hline \multirow{2}{*}{$\begin{array}{l}\text { Fase cres cimento } \\
\text { Variáveis }\end{array}$} & \multicolumn{4}{|c|}{ Niveis de proténs (\%) } \\
\hline & 19,40 & 16,80 & 14,90 & CV \% \\
\hline Peso inicisl - kg & 30,50 & 30,32 & 30,32 & 1,8 \\
\hline Peso final- $\mathrm{kg}$ & 56,67 & 58,62 & 56,65 & 4,4 \\
\hline Ganho em peso relativo - \% & 85,80 & 93,34 & 86,84 & 4,4 \\
\hline Ganho diário de peso - kg & 0,748 & 0,809 & 0,753 & 8,9 \\
\hline Consumo diário de ração - $\mathrm{kg} / \mathrm{d}$ dia & 1,759 & 1,804 & 1,792 & 8,0 \\
\hline Conversão alimentar & 2,36 & 2,24 & 2,38 & 7,9 \\
\hline Duração da fase - dias & 37 & 36 & 37 & 5,0 \\
\hline Margem bruta - RS & 21,52 & 27,00 & 19,12 & - \\
\hline IEE - \%: & 91,01 & 100,00 & 81,88 & - \\
\hline Fase terminação & \multicolumn{4}{|c|}{ Niveis de proteina (\%) } \\
\hline Variáveis & 17,80 & 15,40 & 13,30 & CV\% \\
\hline Peso inicisl - kg & 56,67 & 58,62 & 56,65 & 4,4 \\
\hline Peso final $-\mathrm{kg}^{2}$ & 90,02 & 90,08 & 86,43 & 7,2 \\
\hline Ganho em peso relativo (\%) & 58,85 & 53,67 & 52,57 & - \\
\hline Ganho diário de paso - kg & 0,953 & 0,899 & 0,851 & 14,5 \\
\hline Consumo diário de ração - $\mathrm{kg}$ & 2,493 & 2,607 & 2,469 & 9,1 \\
\hline Conversão alimentar & 2,94 & 2,76 & 2,78 & 9,6 \\
\hline Rendimento carcaça - \% & 78,84 & 80,29 & 79,76 & 1,9 \\
\hline Comprimento de carcaça - cm & 93,08 & 96,50 & 94,33 & 2,7 \\
\hline Peso de Pemil-kg ${ }^{88}$ & 10,717 & 11,900 & 11,167 & 5,9 \\
\hline Rendimento de Pemil - \% & 31,28 & 31,92 & 31,62 & 3,4 \\
\hline ETMED-mm & 25,33 & 26,50 & 27,18 & 10,3 \\
\hline $\mathrm{ET} 2-\mathrm{mm}$ & 23,17 & 23,50 & 23,50 & 14,5 \\
\hline Area de gordura $-\mathrm{cm}^{2}$ & 19,05 & 19,39 & 19,97 & 18,4 \\
\hline Area de olho de lombo $-\mathrm{cm}^{28}$ & 35,86 & 40,56 & 42,77 & 9,2 \\
\hline Relação gordura: came & 0,54 & 0,48 & 0,47 & 21,2 \\
\hline Margem bruta - RS & 9,08 & 4,30 & 0,24 & - \\
\hline IEE - \%: & 100,00 & 91,40 & 81,86 & - \\
\hline
\end{tabular}

da fase anterior em que todas as variáveis indicaram melhores respostas aos animais submetidos à dieta com $16,80 \%$ de proteína bruta, o desempenho das fêmeas não sugere diferenças entre os tratamentos. A ausência de efeito estatístico $(\mathrm{P}>0,05)$ onde ficaram caracterizadas diferenças numéricas, provavelmente, deveu-se ao alto coeficiente de variação (acima de 8\%) visto que houve redução gradativa nos ganhos em peso relativo e diário, na medida em que a concentração protéica foi reduzida. 
Nas características de carcaça, diferenças estatísticas foram observadas nas variáveis: peso de pernil com resposta quadrática $(\mathrm{P}<0,02)(\hat{\mathrm{Y}}=-20,007677+$ $\left.4,161132 X-0,136227 X^{2}, R^{2}=1,00\right)$ com o nível estimado da proteína em 15,28\%; e área de olho de lombo com resposta linear $(\mathrm{P}<0,04)$ definida pela equação $\mathrm{Y}=54,83-$ 0,989144X, $\left(\mathrm{R}^{2}=0,70\right)$.

Das variáveis analisadas, os resultados da avaliação de carcaça são insatisfatórios para indicação do melhor nível de proteína dietética. No caso do peso do pernil $(\mathrm{P}<0,02)$ não se pode assegurar que tenha havido maior acúmulo de carne nos animais submetidos à dieta com $15,40 \%$ de proteína bruta, apesar dos valores indicarem melhores respostas para comprimento e rendimento de carcaça quente. Por si só, as variáveis rendimento de carcaça, peso de pernil e área de olho de lombo à terminação não permitiram diferenciar as frações carne e gordura. A melhor solução, provavelmente, seria a decomposição do ganho em peso corporal em taxas diárias de deposição ou através da dissecação. Diversos autores já destacaram a importância dessa avaliação, visto que algumas variáveis, isoladamente, não refletem a eficiência de utilização dos nutrientes, sobretudo, os que mais se associam ao anabolismo protéico. ${ }^{17}$

Os resultados presentes confirmam observações prévias em que a redução da proteína dietética entre 2,0 e 4,0\% não deprime o desempenho do suíno, se suplementados os principais aminoácidos limitantes. ${ }^{1,3,4,5,6}$

Ao assegurar igual nível de lisina digestível nas diferentes dietas, bem como semelhantes respostas no desempenho, a avaliação econômica passou a ser o indicador do melhor tratamento. Segundo a margem bruta devido à alimentação e o índice de eficiência econômica, a dieta com $17,80 \%$ de proteína bruta, sem a suplementação de aminoácidos industriais, seria a mais vantajosa para fêmeas na fase de terminação. Nessa avaliação, todavia, deve-se levar em conta as condições vigentes para os preços dos ingredientes da ração, visto que o custo da alimentação é a componente mais expressiva no custo final do suíno ao abate, e o preço do suíno à terminação.

Os resultados das variáveis do desempenho, carcaça e avaliação econômica com os machos castrados em fase de crescimento e terminação são apresentados na tabela 3. Não ficaram evidenciadas diferenças estatísticas nas variáveis do desempenho, quando os animais foram submetidos aos diferentes níveis da proteína dietética nas duas fases avaliadas.

$\mathrm{Na}$ fase de crescimento todas as variações numéricas do desempenho de machos castrados indicaram melhor resposta aos animais que foram submetidos à dieta com $14,90 \%$ de proteína bruta. Confirmaram-se as observações destacadas ${ }^{13}$ em relação às situações que a ausência de diferenças estatísticas em parâmetros do desempenho ponderal podem não expressar a real viabilidade do tratamento, quando se trata de produtividade. No estudo em questão, diferenças no número de dias para os animais atingirem o peso ao abate foram constatadas, quando não havia diferenças estatísticas no ganho de peso diário. Os mesmos sugeriram que pequenas diferenças não detectadas no desempenho, em função do coeficiente de variação mais elevado, poderiam ter implicações econômicas relevantes ao término de cada fase experimental, uma vez considerado o ganho em peso acumulado durante um determinado período. No presente estudo, embora, o índice de eficiência econômica seja $100 \%$ para a dieta com $16,80 \%$ de proteína bruta, a maior margem bruta devido à alimentação ocorreu sob a dieta com 14,90\% de proteína, coincidindo com o menor número de dias gastos na fase.

Quanto à vantagem observada como margem bruta devido à alimentação ${ }^{8}$, a dieta com menor nível de proteína bruta mostrouse mais viável se os animais fossem comercializados ao final da fase de crescimento. A redução do maior para o menor nível protéico avaliado em 4,5\%; correspondeu a menos $52,28 \%$ de inclusão do farelo de soja ou $23,19 \%$ da proteína 
Tabela 3 - Desempenho de machos castrados e características de carcaça nas fases de crescimento e terminação alimentados com dieta com diferentes nível de proteína

\begin{tabular}{lcccc}
\hline Fase Crescimento & \multicolumn{4}{c}{ Nível de proteína (\%) } \\
\cline { 2 - 5 } Variáveis & 19,40 & 16,80 & 14,90 & CV\% \\
\hline Peso inicial - kg & 30,63 & 30,85 & 30,73 & 2,2 \\
Peso final - kg & 60,45 & 60,28 & 62,53 & 6,4 \\
Ganho em peso relativo - \% & 97,36 & 95,40 & 100,48 & 6,5 \\
Ganho em peso relativo ajustado - \% 19,79 & 89,96 & 97,61 & 6,4 \\
Ganho diánio de peso - kg & 91,79 & 0,909 & 12,9 \\
Consumo diánio de ração - kg & 0,852 & 0,841 & 0,909 \\
Conversão alimentar & 2,045 & 2,041 & 2,162 & 10,6 \\
Duração da fase - dias & 2,41 & 2,43 & 2,40 & 7,8 \\
Margem bruta - RS & 35 & 35 & 33 & 5,9 \\
ÍEE - \% ${ }^{2}$ & 25,35 & 24,93 & 28,73 & - \\
\hline
\end{tabular}

Fase Terminação

Níveis de proteina (\%)

\begin{tabular}{lcccc} 
Variáveis & 17,80 & 15,40 & 13,30 & CV\% \\
\hline Peso inicial-kg & 60,45 & 60,28 & 62,53 & 6,4 \\
Peso final - kg ${ }^{3}$ & 98,57 & 96,686 & 99,95 & 4,9 \\
Ganho diánio de peso - kg & 0,978 & 0,917 & 0,959 & 13,0 \\
Consumo diário de ração - kg & 3,094 & 3,000 & 3,002 & 9,6 \\
Conversão alimentar & 3,17 & 3,06 & 3,12 & 6,9 \\
Rendimento de carcaça - \%* & 76,91 & 79,46 & 80,82 & 2,3 \\
Comprimento de carcaça - cm & 97,40 & 94,30 & 92,92 & 3,4 \\
Peso de Pemil - kg & 11,640 & 11,920 & 11,650 & 5,2 \\
Rendimento de Pemil - \% & 31,81 & 31,49 & 29,93 & 6,1 \\
ETMED - mm & 28,60 & 28,20 & 32,67 & 15,6 \\
ET2 - mm & 24,00 & 25,40 & 28,67 & 16,4 \\
Área de gordura - cm ${ }^{2}$ & 21,73 & 23,79 & 27,62 & 17,9 \\
Área de olho de lombo - cm ${ }^{2}$ & 38,79 & 37,83 & 38,08 & 11,8 \\
Relação gordura: came & 0,56 & 0,64 & 0,74 & 27,0 \\
Margem bruta - RS & 4,34 & 3,30 & $-0,38$ & - \\
ÍEE - \% & 100,00 & 99,79 & 91,86 & - \\
\hline
\end{tabular}

1.Ganho em peso relativo ajustado para 33 dias; 2 . Indice de eficiência econômica; 3 Pes o ajustado para 39 dias de avaliação (kg); ${ }^{*}$ Efeito Linear $(\mathrm{P}<0,02)$ 
calculada. Nas condições vigentes foi viável a suplementação de lisina, metionina, treonina e triptofano na dieta com menor nível protéico.

Estas respostas ratificam a possibilidade de flexibilizar o nível protéico cerca de 4\% sem haver prejuízos ao desempenho do suíno, desde que se assegurem as exigências dos principais aminoácidos. ${ }^{1,4,5,14}$ Esses autores enfatizaram ainda que além de assegurar o bom desempenho dos suínos em crescimento e terminação, a redução da proteína dietética minimiza a excreção do nitrogênio e aumenta a viabilidade econômica da dieta. Sobre o mesmo assunto, destaca-se a necessidade de informações mais acuradas sobre a utilização conjunta de energia e proteína, observando que a implementação dessa estratégia exigiria mais estudos sobre o tema. ${ }^{18,19}$

$\mathrm{Na}$ fase de terminação (Tabela 3) as respostas do desempenho foram semelhantes aos ocorrido na fase de crescimento, com ausência da variação estatística e possibilidade de redução no nível protéico da dieta em até 4,5\%. Essa medida assegura o desempenho do suíno desde que haja suplementação dos principais aminoácidos, como sugere a literatura consultada.

As variações numéricas observadas nas variáveis do desempenho também ficaram caracterizadas nas medidas efetuadas na carcaça, em favor do menor nível de proteína $(13,30 \%)$. Constatou-se efeito $(\mathrm{P}<0,02)$ linear do nível de proteína no rendimento de carcaça quente, segundo a equação $\hat{Y}=92,68-0,871519 X,\left(R^{2}=0,92\right)$. A redução do nível protéico, portanto, coincidiu com o aumento no rendimento de carcaça. Houve também indicações de que a menor concentração de proteína dietética coincidiu com o aumento da espessura de toucinho, área de gordura e relação gordura: carne. Estas observações indicam a maior deposição de gordura, quando aumenta a energia líquida da dieta, em função do menor incremento calórico, na medida em que diminui a concentração dietética de proteína. Após a fase de crescimento, acentua-se o acúmulo de gordura na carcaça, numa proporção muito superior ao que ocorria com a deposição de proteína na fase anterior. Nesse caso, o incremento calórico promovido pela proteína da dieta pode atenuar essa deposição. Acúmulo de gordura na carcaça na fase de terminação, pode favorecer o rendimento de carcaça quente, contudo, sem haver o correspondente para a porcentagem de carne como sugere o presente estudo.

O efeito estatístico e as variações numéricas constatadas, não obstante, sugerem que a flexibilização da proteína não implicou em melhor qualidade de carcaça. Os acréscimos nas variáveis citadas indicaram acúmulo de gordura corporal à medida que reduziu a proteína da dieta. Coincidentemente, a redução do comprimento de carcaça, com o decréscimo da proteína na dieta, também sugere ganho corporal de gordura e prejuízos ao crescimento e ganho corporal de proteína. Aumento do ganho protéico implica na diminuição simultânea da deposição lipídica na carcaça e essa relação inversa estaria associada a melhor utilização dos aminoácidos. ${ }^{20} \mathrm{E}$, liderado pela lisina os aminoácidos destinam-se à síntese preferencial da proteína muscular esquelética nas fases de maior crescimento. Considerações também foram feitas ${ }^{21}$ sobre a utilização da proteína ou conjunto de aminoácidos, na relação ideal com a lisina, e suas implicações no diferencial entre carne e gordura da carcaça.

Quanto à viabilidade econômica do estudo, observou-se que as dietas com 17,80 e $15,40 \%$ proteína bruta, propiciaram, respectivamente, maiores retornos financeiros na comercialização dos machos castrados à terminação. E, a situação mais viável ocorreu com o fornecimento da dieta de maior nível protéico, sem a suplementação de aminoácidos industriais. Conforme observado no estudo com fêmeas, as condições vigentes para os preços dos ingredientes da ração e do suíno devem ser consideradas, visto o que representa a alimentação no custo final do suíno ao abate. 


\section{Conclusões}

Dessas formulações consideradas padrão, na fase de crescimento, as dietas com 16,80 e $14,90 \%$ de proteína bruta são as indicadas para fêmeas e machos castrados, respectivamente.

$\mathrm{Na}$ fase de terminação, a dieta com $17,80 \%$ de proteína bruta, sem aminoácidos suplementares, seria indicada para fêmeas e machos castrados da genética estudada se o custo do farelo de soja for viável para assegurar a concentração de lisina digestível estuda e o retorno econômico.

Preços do farelo de soja, dos aminoácidos industriais e do suíno determinarão a viabilidade $\mathrm{da}$ estratégia alimentar nessas fases do desenvolvimento.

Outro fator na adoção dos níveis protéicos aplicados aos machos castrados na fase de terminação é o preço do suíno pago pelo frigorífico, no caso da classificação de carcaça, uma vez que a redução dietética da proteína implica em maior acúmulo de gordura corporal.

\section{Agradecimentos}

À Ajinomoto Biolatina pelo auxílio na realização do experimento.

\section{Protein levels in growing and finishing pig diets}

\section{Abstract}

Gilts and barrows, in growing and finishing phases were submitted to different protein levels with or without feed grade amino acid. It was used 72 animals, 36 of each sex, with 30.73 and $30.38 \mathrm{~kg}$ initial average weights (growing phase) and 61.08 and $57.31 \mathrm{~kg}$ (finishing phase), respectively. It was adopted randomized block design with 3 treatments, 6 replications and 2 animals for experimental unit. The treatments were diets with crude protein levels: $19.40 ; 16.80$ and $14.90 \%$ in growing phase diets and 17.8; 15.40 and $13.60 \%$ in finishing phase. In growing phase the diets with 16.80 and $14.90 \%$ of crude protein were indicated to gilts and barrows, respectively. In finishing phase the diet with $17.80 \%$ of crude protein, without additional amino acid is indicate to gilts and barrows of studied genetic if soybean meal cost is capable to assure the digestible lysine level studied and economic return. The price of soybean meal, industrial amino acids and swine will determine the viability of feed strategy in these development phases. Other factor in adoption of applied protein levels to barrows in finishing phase is pig price at slaughter, in the case of carcass classification, because the protein reduction in diet implicates in increased body fat accretion.

\section{Referências}

1 SHRIVER, J. A.; CARTER, S. D.; SUTTON, A. L; RICHERT, B. T.;SENNE,B. W.; PETTEY, A. Effects of adding fiber sources to reduced-crude protein, amino acid-supplemented diets on nitrogen excretion, growth performance, and carcass traits of finishing pigs. Journal Animal Science, v. 81, n. 2, p. 492-502, 2003.

2 GASPAROTTO, L.; MOREIRA, I.; FURLAN, A. C.; MARTINS, E. N.; MARCOS JUNIOR, M. Exigência de lisina, com base no conceito de proteína ideal, para
Key words: Amino Acid. Carcass. Performance. Pig. Requirement. suínos machos castrados de dois grupos genéticos, na fase de crescimento. Revista Brasileira de Zootecnia, v. 30, n. 6, p.1742-1749, 2001.

3 KERR, B. J.; SOUTHER, L. L.; BIDNER, I. D.; FRISEN K. G.; EASTER, R.A. Influence of dietary protein level, amino acid supplementation, and dietary energy levels on growing-finishing pig performance and carcass composition. Journal of Animal Science, v. 81, n. 12, p. 3075-3087, 2003.

4 FIGUEROA, J. L.; LEWIS, A. J.; MILLER, P. S.; FISHER, R. L.; GOMEZ, R. S.; DIEDRICHSEN, R. M. Nitrogen 
metabolism and growth performance of gilts fed Standard corn-soybean meal diets or low-crude protein amino acid-supplemented diets. Journal of Anima Science, v. 80, n.11, p. 2911-2919, 2002.

5 KERR, B. J.; YEN, J. T.; NIENABER, J. A.; EASTER, R. A. Influence of dietary protein level, amino acid supplementation on environmental temperature on performance, body composition, organ weights and total heat production of growing pigs. Journal of Animal Science, v. 81, n. 8, p. 1998-2007, 2003.

6 OTTO, E. R.; YOKOAMA, M.; KU, P. K.; AMES, N. K.; TROTTIER, N. L. Nitrogen balance and ileal amino acid digestibility in growing pigs fed diets reduced in protein concentration. Journal of Animal Science, v. 81, n. 7 , p. $1743-1753,2003$

7 ROSTAGNO, H. S.; ALBINO, L. F. T.; DONZELE, J. L. Tabelas brasileiras para aves e suínos. Composição de alimentos e exigências nutricionais. Viçosa, MG: Universidade Federal de Viçosa, 2005. CD-ROM.

8 GUIDONI, A. L.; ZANOTTO, D. L.; BELLAVER, C. Método alternativo na análise bioeconômica de experimentos com alimentação de suínos. In REUNIÃO ANUAL DA SOCIEDADE BRASILEIRA DE ZOOTECNIA, 34., 1997. Juiz de Fora. Anais... Juiz de Fora: Sociedade Brasileira de Zootecnia, 1997. p. 106-108.

9 GOMES, M. F. M.; BARBOSA, H. P.; FIALHO, E. T.; FERREIRA, A. S.; LIMA, G. J. M. M. de. Análise econômica da utilização do triguilho para suínos. (S.I.): EMBRAPA - Centro Nocional de Pesquisa de Suínos e Aves, 1991, p. 1-2 (Comunicado Técnico, 179).

10 ASSOCIAÇÃO BRASILEIRA DE CRIADORES DE SUÍNOS. Método Brasileiro de Classificação de Carcaça. Estrela, RS: ABCS, 1973. 17 p.

11 CUTHBERTSON, A. PIDA Dissection techniques. In: SYMPOSIUM ON METHODS OF CARCASS EVAluATION, 1968. Dublin. Proceedings... Dublin: European Association for Animal Production, 1968. $8 \mathrm{p}$.

12 STATISTICAL ANALYSIS SYSTEM. SAS user's guide statistics. Version 6.12. Cary: SAS Institute, 1996.

13 TRINDADE NETO, M. A.; BARBOSA, H. P.; PETELINCAR, I. M. Farelo de soja, soja integral macerada e soja micronizada na alimentação de leitões desmamados aos 21 dias de idade. Revista Brasileira de Zootecnia, v. 31, n. 1, p. 104-111, 2002.

14 TUITOEK, J. K.; YOUNG L. G.; DELANGE, C. F.; KERR, B. J. The effect of reducing excess dietary amino acids on growing-finishing pig performance: an evaluation of the ideal protein concept. Journal Animal. Science, v. 75, n. 6, p.1575-1583, 1997.

15 HANNAS, M. I.; OLIVEIRA, R. F. M. de, DONZELE, J. L.; LOPES, D. C.; SOARES, J. L.; MORETTI, A. M Proteína bruta para suínos machos castrados mantidos em ambiente de conforto térmico dos 15 aos $30 \mathrm{~kg}$ Revista Brasileira de Zootecnia, v. 29, n. 2, p. 476-484, 2000.

16 ORLANDO, U. A. D.; OLIVEIRA, R. L. M. de; DONZELE, J. L.; FERREIRA, A. S.; RESENDE, W. O. FREITAS, L. S. Níveis de proteína bruta para leitoas dos 30 aos $60 \mathrm{~kg}$ mantidas em ambiente de conforto térmico $\left(21^{\circ} \mathrm{C}\right)$. Revista Brasileira de Zootecnia, v. 30, n. 6, p.1760-1766, 2001.

17 SUSENBETH, A. Factors affecting lysine utilization in growing pigs: an analysis of literature data. Livestock Production Science, v. 43, n. 3, p. 193-204, 1995.

18 NOBLET, J. Impact of dietary crude protein on metabolic utilization of energy in pigs. In: LATIN AMERICAN COLLEGE OF ANIMAL NUTRITION, 2003. Disponível em: <www.engormix.com/ e articles.asp? $I D=100>$. Acesso em: 13 jun. 2005.

19 NOBLET, J. Protein and energy requirements of growing swine. In: SIMPÓSIO INTERNACIONAL SOBRE EXIGÊNCIAS NUTRICIONAIS DE AVES E SUÍNOS, 2., 2005, Viçosa. Anais... Viçosa, MG, 2005. p. $175-198$.

20 FRIESEN, K. G.; NELSSEN, J. L.; GOODBAND, R. D.; TOKACH, M. D.; SCHINCKEL, A. P. The use of compositional growth curves for assessing the response to dietary lysine by high-lean growth gilts. Animal Science, v. 62, n. 1, p. 159-169, 1996.

21 CROMWELL, G. L.; CLINE, T. R.; CRENSHAW, J. D.; CRENSHOW, T. D.; EWAN, R. C.; HAMILTON, C. R.; LEWIS, A. J.; MAHAN, D. C.; MILLER, E. R.; PETTIGREW, J. E. The dietary protein and (or) lysine requirements of barrows and gilts. Journal Animal Science, v. 71, n. 6, p. 1510-1519, 1993. 